\title{
SOCIAL ASPECTS OF PEPTIC ULCER
}

\author{
By F. Avery Jones, M.D., F.R.C.P. \\ Physician in Charge of Gastro-Enterological Department, Central Middlesex Hospital, Member of Teaching Staff The \\ Middlesex Hospital, Consultant in Gastro-Enterology to the Postgraduate Medical School of London, to St. Mark's Hospital \\ and to the Royal Navy
}

Although it is convenient to refer to peptic ulcer, it is important to appreciate that gastric ulcer and duodenal ulcer may be two entirely different diseases with their own separate aetiological factors. Statistical studies reveal a number of striking differences in behaviour between gastric and duodenal ulcers. The position is further complicated by juxta-pyloric ulcers which seem to have a closer affinity with the duodenal group than with the gastric group.

One of the fascinating aspects of the problem is the striking change in the frequency and type of ulcer during this century. At the turn of the last century at least half the admissions for acute perforation or haemorrhage occurred in young women under 25 with acute gastric ulcers, but today such ulcers in this age-group are extremely rare. While these acute gastric ulcers in young women declined, there was a considerable male increase in the prevalence of chronic peptic ulcer, mainly pyloro-duodenal ulceration. A striking increase took place after the first world war, particularly between 1920 and 1930, and again at the beginning of the second world war. This trend was well demonstrated by Illingworth, Scott and Jamieson, who analysed the admissions for acute perforations to Glasgow hospitals between 1924 and 1943 and showed that the incidence per 100,000 population doubled between 1924 and 1934 and that this increase was entirely attributable to juxta-pyloric and duodenal ulcer in men. It is to be noted that there was no increase in the number of admissions from perforations of chronic gastric ulcers. This aspect has been well reviewed by Bager (1929) and Jennings (1940) and no matter whether the statistics of Germany, France or Scandinavia are studied, the same trend appears. The available evidence suggests that there has been a true increase in prevalence and not merely better diagnosis.

The present size of the problem as it affects the general population has been the subject of a recent survey (Doll and Avery Jones, 1952). From an individual study of 6,047 men and women in various occupations mainly in London, it could be calculated that the incidence of those who have had or still have peptic ulcer in London was 5.8 per cent. for men between the age of 15 and 64 and 1.9 per cent. for women in the same age group. If geographical differences are neglected and the age and sex rates were applied to England and Wales as a whole, the total number of persons then living who have or have had peptic ulcer was around $r, 449,000$, while the number of men each year who suffered from symptoms was estimated at 638,000 . The incidence varied markedly with age, reaching a maximum between 45 and 54 and then decreasing.

Clearly a disease of this prevalence is of importance in the national economy. It is, however, not one of the important killing diseases and accounts for only I per cent. of all deaths, approximately 5,000 a year in England and Wales, a figure equal to the number killed on the roads. The average loss of working time represents approximately 38.8 days of absence per 100 men in a year (Doll and Buckatszch, 1949). Such figures give little clue to the immense amount of personal disability suffered by many while continuing at work. The burden of pain is not evenly divided; about one-third of those who have had peptic ulcer have suffered very little disability, rather more than one-third can live on reasonable terms with their stomach provided they exercise considerable care, while the remaining individuals are more seriously incapacitated by crippling attacks, or serious complications. The pressure of this disease is felt particularly in hospitals and a survey of 12 general hospitals showed that out of 4,1 I 7 general adult beds, medical and surgical, 372 (9 per cent.) were occupied by cases of peptic ulcer. Haemorrhage, perforation, stenosis or the need for surgical treatment are the usual reasons for admission and relatively few of the many patients with uncomplicated ulcers are admitted to hospital, and of these only a small proportion can be kept in 
until healing is complete. Those with dyspepsia constitute an important proportion of out-patient attendances at hospital and impose a heavy strain on the radiological departments.

\section{Sex Incidence}

Peptic ulcer is essentially a disease of men, approximately 80 per cent. of patients being males. It appears that during the reproductive period of life, women have a relative immunity to peptic ulcer, an immunity which is particularly marked during pregnancy and seems to decline sharply with the menopause. Hospital experience indicates a particular deficiency of duodenal ulcer among women $(M / F, 6: I)$, but for acute rapidly healing gastric ulcers causing bleeding the sex incidence is the same $(M / F, I: I)$ (Avery Jones and Pollak, 1945). Considering the emphasis on the anxiety factor in recent years in the genesis of peptic ulcer, it is worth noting that the complications of ulcer are virtually unknown in relation to pregnancy in unmarried women.

\section{Age Incidence}

From the age of onset of the observed ulcers in the population survey and the number of manyears lived at each age, it was possible to calculate the annual expectation of developing an ulcer: Contrary to prevailing opinion, the expectation of developing a peptic ulcer is almost constant and is probably at its maximum between 35 and 64 , giving a rate of 3.2 ulcers per 1,000 men. It is likely that the idea that ulcers occur more frequently in young men is due to a failure to take into account the relative size of the population at risk. It is interesting to note that gastric and duodenal ulcers behave differently; the liability to develop a duodenal ulcer is almost constant between 20 and 55, while the risk of developing a gastric ulcer increases slowly up to the age group 35 to 44 .

\section{Social Class Incidence}

There are marked social class differences in the incidence as shown in Fig. I. Duodenal ulcers are evenly distributed through the social classes, but there is a noticeable deficiency of gastric ulcers in the professional groups and a striking excess among the labouring groups.

This social class difference between gastric and duodenal ulcer may be one factor in causing the striking discrepancies in the ratio of gastric to duodenal ulcers in some countries with varying standards of living. It is possible that the higher standard of living among workers in the U.S.A. may account for the low proportion of gastric ulcers as compared with Great Britain. It is

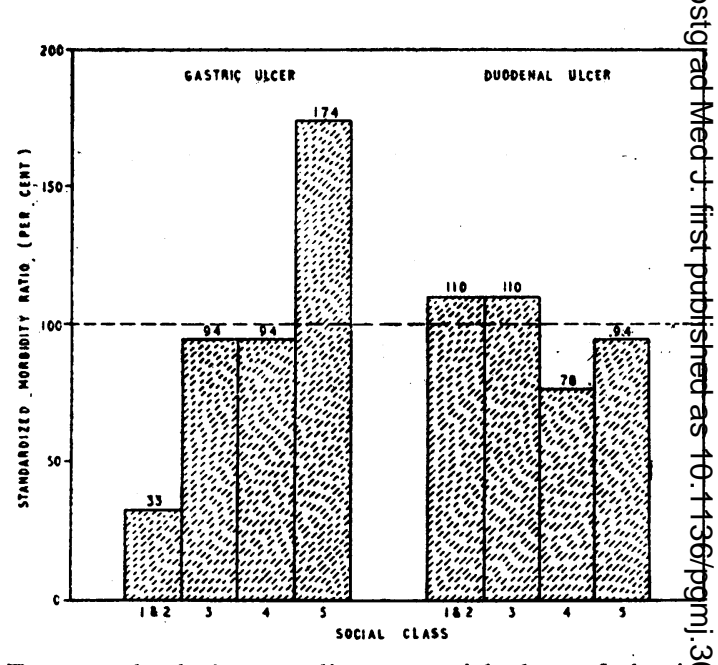

FIG. 1.-Analysis according to social class of the if cidence of gastric and duodenal ulcer in men, the incidence being calculated as the standardized morbidity ratio on the same basis as the Registrar: General's standardized mortality ratio. The valuo for the standardized morbidity ratio is shown above each column.

certainly not the whole explanation. Variation 苗 the G.U./D.U. ratio may equally well be relate] to an increase in duodenal ulcer, which may count for the higher proportion of duodes id ulcers in Glasgow (12:I) as compared with Lon $(3: 1)$. This social class distribution may not bot generally applicable and needs testing in differeng countries. It certainly does not obtain fơ Southern India where duodenal ulcer is essentialP a disease of the very poor. Unfortunately no population surveys have been made in othe countries and it is impossible to compare absolute incidences of G.U. and D.U. but only ratios: One geographical variation which has been cor firmed elsewhere is the clear difference between town and rural areas. An analysis of the Registrags. General's mortality figures by Morris and Titmus (1944) showed that the mortality rates of pepte ulcer for men over 45 was approximately 75 per cent. higher in the County of London than in the rural areas of England and Wales, and similes indications are provided by Bager (1929) for Sweden and by Ginannesschi (1938) for Italy. N

\section{Occupational Incidence}

The population survey provided confirmatory evidence concerning rural populations in that low incidence of ulcer was found among agricue tural workers. Whether this was due to a re9 immunity from the country life, or whether the ulcer-prone men have left the land and gone to the cities remains to be determined. 
TABLE 2

Occupations with InCidence above Average

\begin{tabular}{|c|c|c|c|}
\hline Occupation & $\begin{array}{l}\text { No. of } \\
\text { Men }\end{array}$ & $\begin{array}{l}\text { No. of } \\
\text { P.U.s. }\end{array}$ & $\begin{array}{l}\text { Standardised } \\
\text { morbidity } \\
\text { ratio }\end{array}$ \\
\hline Doctors . . . . & 127 & 15 & 232 \\
\hline Business executives & 98 & I I & I55 \\
\hline $\begin{array}{l}\text { Foremen } \\
\text { Social class } \\
4\end{array}$ & 253 & 27 & 137 \\
\hline $\begin{array}{l}\text { (unclassified) } \\
\text { Semi-skilled }\end{array}$ & 377 & 31 & 113 \\
\hline & 298 & 21 & I I \\
\hline $\begin{array}{l}\text { workers } \\
\text { Bus and }\end{array}$ & 597 & 37 & 109 \\
\hline \begin{tabular}{lll}
\multicolumn{2}{c}{ drivers } & \\
Social class & $\cdots$
\end{tabular} & 395 & 32 & 107 \\
\hline $\begin{array}{l}\text { (unclassified) } \\
\text { Workers in respon- } \\
\text { sible positions in } \\
\text { industry .. }\end{array}$ & 227 & 38 & 105 \\
\hline
\end{tabular}

OcCupations With INCIDENCE BeI.oW Average

\begin{tabular}{|c|c|c|c|}
\hline Occupation & $\begin{array}{l}\text { No. of } \\
\text { Men }\end{array}$ & $\begin{array}{l}\text { No. of } \\
\text { P.Us. }\end{array}$ & $\begin{array}{l}\text { Standardised } \\
\text { morbidity } \\
\text { ratio }\end{array}$ \\
\hline $\begin{array}{l}\text { Lorry drivers } \\
\text { Heavy manual wor- } \\
\text { kers, semi-skilled } \\
\text { and unskilled .. }\end{array}$ & 178 & 12 & 95 \\
\hline $\begin{array}{l}\text { Clerks } \\
\text { Bus and }\end{array}{ }^{*}$ trolley & $\begin{array}{l}779 \\
342\end{array}$ & $\begin{array}{l}5^{2} \\
20\end{array}$ & $\begin{array}{l}94 \\
92\end{array}$ \\
\hline $\begin{array}{lll}\text { conductors } & & \cdots \\
\text { Social classes } & \text { I } & \&\end{array}$ & 269 & 12 & 72 \\
\hline $\begin{array}{ll}\quad \text { (unclassified) } & \ldots \\
\text { Waiters } & \text { Higher Civil }\end{array}$ & $\begin{array}{l}461 \\
126\end{array}$ & $\begin{array}{r}12 \\
5\end{array}$ & $\begin{array}{l}69 \\
63\end{array}$ \\
\hline $\begin{array}{l}\text { Servants } \\
\text { Agricultural workers } \\
\text { Sedentary workers. }\end{array}$ & $\begin{array}{l}143 \\
203 \\
946\end{array}$ & $\begin{array}{r}8 \\
5 \\
40\end{array}$ & $\begin{array}{l}62 \\
41 \\
75\end{array}$ \\
\hline
\end{tabular}

A high incidence of duodenal ulcer was found among doctors and in a residual group of unskilled workers, but both these may be artificial, due in the first group to more refined standards of diagnosis and in the second to the sheltered employment chosen by ulcer subjects. Taking groups of workers in responsible positions in industry, foremen and business executives, a significant excess of ulcers was found, due almost entirely to an excess of proved duodenal ulcers. In addition to the agricultural workers, a low incidence was found among sedentary workers, but the significance of the latter figure depends on the validity of combining in one group, clerks, higher Civil Servants, students, research workers and draughtsmen. Contrary to popular belief, bus drivers and conductors showed the same incidence as those engaged in industry. No evidence was obtained of any harmful effect of shift work.

\section{Hereditary Factors in Peptic Ulcer}

There is no doubt that the prevalence of ulcer is greater among the relatives of ulcer subjects than among the general population. There have been a number of reports of the prevalence of ulcer in the near relatives of ulcer subjects and among controls, but the difficulty has been to overcome the objection that the patient with an ulcer is more likely to be interested in searching out similar cases in his family than the patient who is suffering from some entirely different disease. In Russia, Levin and Kuchur (1936) overcame this difficulty by comparing near relatives of ulcer patients with 500 members of the general public and found ulcers three times as frequent in the former group. Using the population survey for a control, Doll and Buch (1950) have confirmed this excess incidence in this country.

From Table 3 it appears that there is a tendency for the incidence of ulcers to be higher when the age of onset is earlier and when the site is in the duodenum, but in neither case is the difference statistically significant. Furthermore, evidence has been found for the separate inheritance of gastric and duodenal ulcers (Doll and Kellock, 195I). Relatives of gastric ulcer patients tend to have gastric ulcers and the relatives of duodenal ulcer patients tend to have duodenal ulcer, and this appears to hold for the site of ulcer in different generations as well as the same generation.

TABLE 3

Variations with Age of ONSET aNd Site of Ulcer

\begin{tabular}{l|c|c|c|c}
\hline & \multicolumn{4}{|c}{ Sibs (aged 14-64) } \\
\cline { 2 - 4 } Propositi & $\begin{array}{c}\text { No. } \\
\text { Liv- } \\
\text { ing }\end{array}$ & $\begin{array}{r}\text { Proved Ulcers } \\
\text { Ob- } \\
\text { served }\end{array}$ & $\begin{array}{c}\text { Ex- } \\
\text { pected }\end{array}$ & $\begin{array}{c}\text { Ratio between } \\
\text { observed and } \\
\text { expected ulcers }\end{array}$ \\
\hline $\begin{array}{l}\text { Onset of } \\
\text { symptoms : }\end{array}$ & & & & \\
$\begin{array}{l}\text { Under 35 .. } \\
\text { 35 and over }\end{array}$ & 440 & 36 & 13.40 & $2.7: 1$ \\
$\begin{array}{l}\text { Not known } \\
\text { Site of ulcer: }\end{array}$ & 29 & 33 & 16.08 & $2.0: 1$ \\
Stomach .. & 380 & 25 & 13.71 & $1.8: 1$ \\
$\begin{array}{l}\text { Duodenum } \\
\text { Stomach and } \\
\text { duodenum }\end{array}$ & 469 & 36 & 13.65 & $2.6: 1$ \\
\hline
\end{tabular}

It would seem that gastric and duodenal ulcers must be mainly independent from the point of view of heredity. The interpretation of this hereditary pattern is still in doubt. Is it due to hereditary altered tissue resistance or susceptibility or should, as Kirschner and Palmer (1953) suggest, the attention be directed to environmental factors and to ' hereditary habits' rather than hereditary tendencies? More information is certainly re- 
quired about the role of hereditary habits and twin studies will be needed to solve this aspect of the problem. There may be a physical characteristic associated with the inheritance and a constitutional type for duodenal ulcer was postulated by Hurst. He thought that duodenal ulcer patients tended to be hypersthenic, i.e. they had a short chest, wide high costal angle, long abdomen and a hypotonic stomach, whereas gastric ulcer patients tended to be the opposite or hyposthenic type, but the evidence on this point is still inconclusive. Feigentaun and Howat (1935) failed to find any correlation between anatomical structure and predisposition to ulcer. There is special need for more information about the secretory pattern in the relatives of ulcer subjects and these studies are in progress.

\section{Personality and Ulcer Incidence}

Are peptic ulcers more likely to develop in people with a particular personality, about which so much has been written? Kaufmann (1918) thought that ulcer patients were highly-strung and over-active individuals. Robinson (1937), from a study of 500 patients, thought that a large proportion of them belonged to a definite type with a similar emotional response to conflict; they displayed a relatively calm exterior and did their worrying alone and within. $\mathrm{He}$ found them alert, over-conscientious individuals and very independent. Draper (1945) describes them as having an exaggerated fear sense and regarded them as classical extroverts, beneath an outward manner of assurance. Moses (1946) also stresses the considerable facade of independence and aggression covering a chronic all-pervading sense of insecurity and inferiority. Thus, a patient with peptic ulcer is commonly thought to be ambitious, over-active, over-conscientious and over-sensitive. This personality has been regarded by many as an important aetiological factor, but with the exception of Morrison and Feldman (1942) and Kellock (195I) no investigators seem to have considered that some, if not all, of these characteristics might be the consequence rather than the cause of the disease. Moreover, very few have attempted to show that this personality is commoner among patients with ulcer than among the general population.

By no means all authors are agreed that all patients with ulcer show this type of personality. Thus Kapp, Rosenbaum and Romano (1947) thought that only 6 out of 20 men with duodenal ulcer have the traditional personality picture.

Approaching this problem with an entirely open mind, Kellock (195I) completed a questionnaire designed to bring out personality facets and these were scored by myself without knowing whether they referred to ulcer patients or to the controls. It proved impossible to demonstrate any difference between the two groups. Brown et al. (1950), using a Rorshach test and again being unaware of the identity of the patient or control, found no difference in the mean score though the ulcer group was more homogeneous. Hamilton (1950), using the questionnaire technique, also failed to show any difference between patients with peptic ulcer and the controls. If the ulcer population were, in fact, more ambitious, they would be expected to demonstrate a greater tendency to climb the social scale than controls, but Kellock did not find any difference between ulcer patients and controls in this respect.

\begin{tabular}{|c|c|c|c|c|c|}
\hline Social & Class of & PARENT & - AND & Patient & \\
\hline \multirow[t]{2}{*}{$\begin{array}{l}\text { D.U. } \\
\text { (164) }\end{array}$} & $\begin{array}{l}\text { Class } \\
\text { I \& } 2 \\
3 \\
4 \& 5\end{array}$ & & $\begin{array}{l}\text { ather } \\
18 \\
05 \\
38\end{array}$ & $\begin{array}{r}\text { Son } \\
\times 8 \\
\times 15 \\
31\end{array}$ & \\
\hline & & $\begin{array}{r}\text { Up } \\
\text { Same } \\
\text { Down }\end{array}$ & $\begin{array}{l}39 \\
87 \\
35\end{array}$ & & \\
\hline $\begin{array}{c}\text { Control } \\
(164)\end{array}$ & $\begin{array}{c}\text { Class } \\
\text { I \& } 2 \\
3 \\
4 \& 5\end{array}$ & & $\begin{array}{l}\text { ather } \\
23 \\
100 \\
40\end{array}$ & $\begin{array}{r}\text { Son } \\
13 \\
116 \\
35\end{array}$ & \\
\hline & & $\begin{array}{r}\text { Up } \\
\text { Same } \\
\text { Down }\end{array}$ & $\begin{array}{l}35 \\
93 \\
35\end{array}$ & & \\
\hline
\end{tabular}

The thesis that peptic ulcers tend to develop $\overrightarrow{\overrightarrow{0}}$ particularly in those who are over-sensitive, overactive and over-conscientious rests on insecure evidence. Nor could any support be found for a psychosomatic origin of the disease dating back to early childhood. In view of the stress placed by many writers on the role of childhood in deter- $\frac{\sigma}{3}$ mining a personality liable to psychosomatic disease, it is surprising that so little information 0 exists on this point. Mittelmann and Wolff (1942) considered from a study of 30 patients that the 을 failure of the home in every instance to lend a stable background resulting from a variety of causes (unhappy married life of parents, loss of N the father in childhood) was a cause of the ulcer. $N$ Moses (r949) also considered childhood important in this connection and stated that the "majority $\omega$ of these individuals came from broken homes and from a marginal economic level with its limited social and educational opportunities. Emotionally they were frustrated early in life.' Ruesch (1948) has probably written more about the childhood of ${ }^{-}$ patients with peptic ulcer than anyone else and $\vec{D}$ 
makes the following statement: "Ulcer bearers were generally the youngest or younger born children in the family. In terms of years they were separated from their older and younger siblings ... Our patients were on the average between three and six years old at the birth of a subsequent child.'

All these points, however, were capable of confirmation or refutation. The large-scale study by Kellock has not provided any support for any of the previously-quoted statements and this table shows that duodenal ulcer patients have had the same variety of childhood experiences as the rest of the population.

\section{TABLE 5}

Death of father before patient $15 \ldots$

Death of mother before patient I 5 .. . .

Death of both parents before patient $15 \ldots$

Separation from father before patient 15 . .

Separation from mother before patient $\mathbf{I}_{5} \ldots$

Separation from both parents before patient I 5 .. .. . .

Divorce or separation of parents before patient $15 \ldots$
(250)

(250) 39 $3 \mathbf{r}$

7
Admittedly this does not disprove Moses' statement (1946) that their 'fathers tend to be indifferent and unimportant and their mothers unloving and over-protective.' These negative studies would make such a hypothesis unlikely. Psychoanalytical studies would place the psychic trauma even earlier. Garma (1950) treated six patients with peptic ulcer by psychoanalysis and considered that the ulcer was an 'internal digestive bite,' self-inflicted, ' provoked by remorse on account of oral aggressive wishes against the mother's frustrating breast '-an explanation which is unlikely to appeal to most patients and is, indeed, fantastic nonsense.

Even if no particular personality is associated with peptic ulcer, it remained a possibility that ulcer subjects have had more emotional trauma as adults to contend with, but again no support could be found for this thesis. Kellock compared the frequency of I I causes of potential stress. These were death or illness of father, mother, wife, child or other person closely related emotionally, divorce, separation or other matrimonial difficulties, insecurity of employment and housing difficulties. It was felt that these represented the majority of the common causes of sustained tension. From this rather crude assessment of the amount of strain encountered, there was no evidence that the ulcer patients had been more unfortunate in life than the controls. As far as these particular points were concerned, the controls had suffered from 66 periods of tension since leaving school, the duodenal ulcer patients from $7 \mathrm{I}$ and the gastric ulcer patients from 77 . Clearly there is little difference here and the slight excess among the gastric ulcer patients, if not a chance finding, could be attributed to the fact that they were slightly older and had, therefore, had a greater chance of meeting misfortune.

From these studies there is clearly little support for psychosomatic factors being a major, primary aetiological cause, but nevertheless few would doubt that emotional trauma like other forms of stress act as important aggravating factors and may indeed precipitate a relapse or a complication.

\section{Summary}

I. There has been a striking change in the incidence of peptic ulcer in this century.

2. There are important differences between G.U. and D.U. in their social class distribution.

3. There is an increased familial tendency to gastric and duodenal ulcer and the two appear to behave independently.

4. There are certain occupational differences in incidence.

5. There is no definite personality pattern associated with peptic ulcer.

6. Anxiety like other forms of stress acts as an aggravating factor.

\section{BIBLIOGRAPHY}

BAYER, B. (1929), Acta. Chir. Scand., 64, Suppl. I I.

BROWN, M., BRESNAHAN, T. J., CHALKER, F. C. R., PETERS, B., POSER, E. G., and TOUGAS, R. U. (r.950) Psychosomatic Med., 13, I.

DOLL, R., and BUCKATSZCH, M. M. (1949), Brit. F. Ind. Med., 6, 100 .

DOLL, R., and JONES, F. AVERY (195I), 'Occupational Factors in the Aetiology of Gastric and Duodenal Ulcer,' M.R.C. Special Report Series No. 276 .

DOLL, R., and BUCH, J. (1950), Ann. Eug., 15, 135.

DOLL, R., and KELLOCK, T. D. (1951), Ibid., 16, 231.

DRAPER, G. (1930), ' Disease and Man,' London.

FEIGENBAUM, J., and HOWAT, D. (1935), Arch. Int. Med. $55,445$.

GARMA, A. (1950), Inst. F. Psychoanal., 31, 53.

GINANNESSCHI, G. (1938), Med. Lavoro, 29, 65.

HAMILTON, MAX (1950), Brit. F. Med. Psych., 23, 182.

ILLINGWORTH, C. F. W., SCOTT, L. D. W., and JAMIESON R. A. (1944), Brit. med. F., ii, 617,655 .

JENNINGS, D. (1940), Lancet, i, 395, 444 .

KAUFMANN, J. (1918), Med. Res. N.Y., 94, 324.

KAPP, F. T., ROSENBAUM, M., and ROMANO, J. (1947), Amer. F. Psychiat., 103, 700 .

KIRSCHNER, J. B., and PALMER, W. L. (1952), Amer. F. Med. 13,615 .

KELLOCK, T. D. (1951), Brit. med. F., ii, I 117 .

KELLOCK, T. D. (1951), M.D. Thesis, Univ. of Cambridge.

LEVIN, A. E., and KUCHUR, B. A. (1936), Proc. Maxim Gorky Med-Genet Res. Inst., 4, 181 .

MITTLEMANN, B., and WOLFF, H. G. (1942), Psychosomatic Med., 4, 5.

MORRIS, J. N., and TITMUSS, R. M. (1944), Lancet, ii, 84I.

MORRISON, S., and FELDMAN, M. (1942), f. Amer. Med. Ass., 120, 738.

MOSES, L. (1946), Psychosomatic Med., 8, 405.

ROBINSON, S. C. (1937), Illinois Med. F., 71, 338.

RUESCH, J. (1948), 'Duodenal Ulcer,' Univ. of California Press' 